\title{
Mechanisms of sulphur dioxide induced bronchoconstriction in normal and asthmatic man
}

\author{
PHILLIP D SNASHALL, CAROLINE BALDWIN \\ From the Department of Medicine, University of Southampton Medical School, Southampton
}

ABSTRACT We have examined the inhibitory effect of atropine and sodium cromoglycate (SCG) on the bronchial response to sulphur dioxide $\left(\mathrm{SO}_{2}\right)$ in groups of normal and asthmatic subjects. Eleven normal subjects were premedicated with propranolol (100 mg orally) one hour before each experiment. After baseline measurements of specific airways conductance (sGaw) the subject inhaled an aerosol from a Wright nebuliser for five minutes. In separate experiments this contained water (control), atropine methonitrate $(0.2 \%)$, or SCG $(1 \%)$. Fifteen minutes later sGaw was remeasured and the subject then breathed $\mathrm{SO}_{2}(8 \mathrm{ppm})$ for three minutes through the mouth. Specific airways conductance was measured for the duration of the subsequent response. Intervals between experiments on any one subject were one week or more. After control $\mathrm{SO}_{2}$ inhalation sGaw decreased in all subjects (mean $34 \pm 17(\mathrm{SD}) \%$ ). Atropine and SCG significantly inhibited the $\mathrm{SO}_{2}$ response ( $\mathrm{p}<0.01$ for both). After atropine the mean decrease in sGaw was $13 \pm 24 \%$; after SCG $16 \pm 12 \%$ (range $-3-+55 \%$ ). With atropine the degree of inhibition was inversely related to the subject's responsiveness to the control $\mathrm{SO}_{2}$ inhalation $(\mathrm{r}=-0.75 ; \mathrm{p}<0.01)$. In four asthmatics (without beta-blockade and with lower $\mathrm{SO}_{2}$ exposure) atropine did not inhibit the $\mathrm{SO}_{2}$ response; $\mathrm{SCG}$ had a similar effect to that seen in normal subjects. Therefore, vagal efferent mechanisms are involved in the bronchial response to $\mathrm{SO}_{2}$ in normal subjects, but the lack of inhibition caused by atropine in hyperreactive normal and asthmatic subjects suggests that vagal mechanisms are not important in the causation of hyperreactivity to $\mathrm{SO}_{2}$. The mechanism of inhibition with $\mathrm{SCG}$ is unknown.

Inhalation of low concentrations (5-15 parts per million (ppm) ) of $\mathrm{SO}_{2}$ increases airway resistance in man. ${ }^{12}$ In normal subjects Nadel $e t a^{3}$ found that the rise in airway resistance was prevented by atropine, but in asthmatics Booij-Noord et al ${ }^{2}$ could not block the $\mathrm{SO}_{2}$ response with an anticholinergic agent, or by ganglion blockade. De Vries et al showed that the response to $\mathrm{SO}_{2}$ of asthmatics was partially inhibited by sodium cromoglycate.

In this study we have examined the effect of atropine and sodium cromoglycate on the bronchial response to $\mathrm{SO}_{2}$ of normal and asthmatic subjects. We have also examined the reproducibility of the response to $\mathrm{SO}_{2}$ at various time intervals. The results of this study have been presented previously in abstract. ${ }^{5}$

\section{Methods}

The normal subjects were 11 healthy physicians and

Address for reprint requests: Dr P Snashall, Department of Medicine, Charing Cross Hospital Medical School, Fulham Palace Road, London W6 8RF. laboratory workers (table 1) in all of whom we studied the blocking effects of atropine and sodium cromoglycate. In four of these subjects we studied the reproducibility of the $\mathrm{SO}_{2}$ response in addition.

We also examined the blocking effect of atropine and sodium cromoglycate in four asthmatics (table 1). Three of these were atopic with symptoms beginning in childhood, positive family history and positive cutaneous sensitivity tests to several allergens. The other asthmatic developed symptoms of asthma in his fifth decade, had no known allergies, negative family history, and negative skin tests. Symptoms in the atopic subjects were mild; one subject was asymptomatic apart from exercise-induced wheezing, while the other two had intermittent mild wheezing attacks, usually at night, relieved by inhaled salbutamol, and they were also taking sodium cromoglycate regularly. Both salbutamol and sodium cromoglycate were discontinued 24 hours before the experiments. The non-allergic asthmatic had severe symptoms requiring continuous treatment with prednisolone and corticotrophin, and intermittent salbutamol inhalation. Although this subject's drugs could not be dis- 
Table 1 Experimental subjects

\begin{tabular}{lcccccc}
\hline & No & Age $(y r)$ & Smokers & Atopic & FEV & Measured \\
& & & & Predicted \\
\hline Normals & 11 & 29.4 & 5 & 0 & 3.66 & 3.61 \\
Asthmatics & 4 & $(20-39)$ & 0 & 3 & 2.68 & 3.43 \\
& & $(25-61)$ & & & \\
\hline
\end{tabular}

continued, he did not receive salbutamol over the 12 hours before each experiment. Two of the asthmatics were physicians; all had previously attended the laboratory on several occasions for similar testing of their bronchial reactivity.

In addition to the study with atropine and sodium cromoglycate, one of the atopic asthmatics was a subject in the studies of the reproducibility of the $\mathrm{SO}_{2}$ response.

All the subjects were volunteers who were fully informed about the procedure and its experimental nature.

Normal subjects received propranolol $(100 \mathrm{mg})$ orally one hour before inhalation of $\mathrm{SO}_{2}{ }^{6}$ We measured airway resistance (Raw) and thoracic gas volume (Vtg) using a constant volume body plethysmograph. ${ }^{7}$ Vtg is the lung volume at which the subject performs the panting manoeuvre which is known to be above FRC. In general we have presented our results in terms of "specific" airways conductance, sGaw $\left(=\left(\operatorname{Raw} \times \mathrm{Vtg}^{-1}\right)\right.$, the conductance per unit lung volume. To establish a baseline, we made duplicate measurements at minute intervals for five minutes, after which the subjects inhaled an aerosol from a Wright nebuliser powered by compressed air at $10 \mathrm{l} / \mathrm{min}$ for five minutes (average volume nebulised $=2.0 \mathrm{ml}$ ). In the first experiment on each subject the aerosol was of distilled water, but in subsequent experiments we used aerosols of atropine methonitrate $(0.2 \%)$ and sodium cromoglycate $(1 \%)$ in random order. Two subjects received sodium cromoglycate in the form of a powder $(20 \mathrm{mg})$ using the standard "spinhaler". The subject re-entered the plethysmograph 10 minutes after aerosol inhalation and we made duplicate measurements of Raw and Vtg at minute intervals for 10 minutes.

The subject then sat outside the plethysmograph and breathed $\mathrm{SO}_{2}$ from a mixing chamber at a concentration of $8 \pm 0.5 \mathrm{ppm}$. The mixing chamber was fed with $\mathrm{SO}_{2}$ (in air) and air from cylinders, both at accurately known flow rates. The diluted gas $(20 \mathrm{l} / \mathrm{min})$ left the mixing chamber through a long wide-bore tube (volume two litres) to be discharged outside the laboratory. The subject breathed via a two-way respiratory valve from a side port of this tube close to the mixing chamber. This arrangement allowed the subject to take a breath of up to two litres at correct concentration without appreciably altering the pressure in the system. The subject's expired gas was also discharged outside the laboratory.

Normal subjects breathed the mixture for three minutes; three of the asthmatics for one minute; one atopic asthmatic who was known to be highly reactive to a variety of stimuli was given $4 \mathrm{ppm}$ for 30 seconds only. The subject then re-entered the plethysmograph and we made the first measurements of Raw and Vtg within 60 seconds of the end of $\mathrm{SO}_{2}$ inhalation. We used an identical procedure for the blocking experiments with atropine and sodium cromoglycate.

To assess the size of the response to $\mathrm{SO}_{2}$ we have compared the mean of the last five consecutive

Table 2 Response to $\mathrm{SO}_{2}$

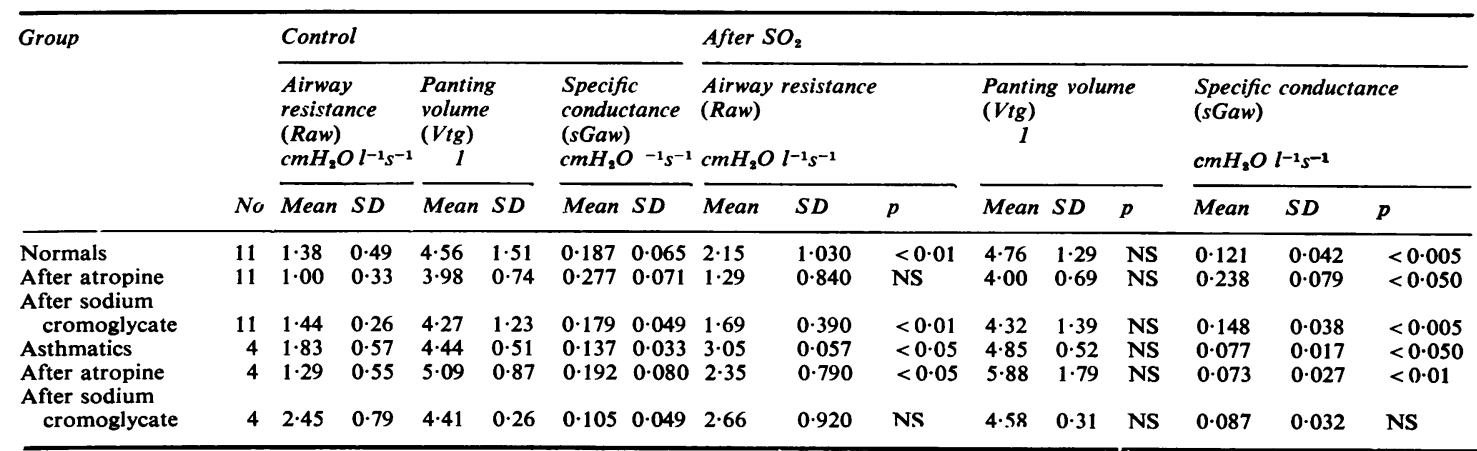


measurements before $\mathrm{SO}_{2}$ with the mean of the first five consecutive measurements after inhalation. The interval between exposures was usually a week or more. We performed the experiments at the same time of day on each occasion.

We studied the effect of repetition on the size of the $\mathrm{SO}_{2}$ response in two groups of five normal subjects and one asthmatic. One group was reexposed at four hours, the other at 24 hours. The normal subjects re-exposed at 24 hours were given propranolol $(100 \mathrm{mg})$ before both exposures, but the four-hour re-exposure subjects did not receive a second dose of propranolol.

\section{Results}

RESPONSE TO $\mathrm{SO}_{2}$ (TABLE 2)

Normal subjects $($ fig 1$)$

Inhalation of $\mathrm{SO}_{2}$ resulted in an increase of airway resistance (Raw) and a fall of specific airways

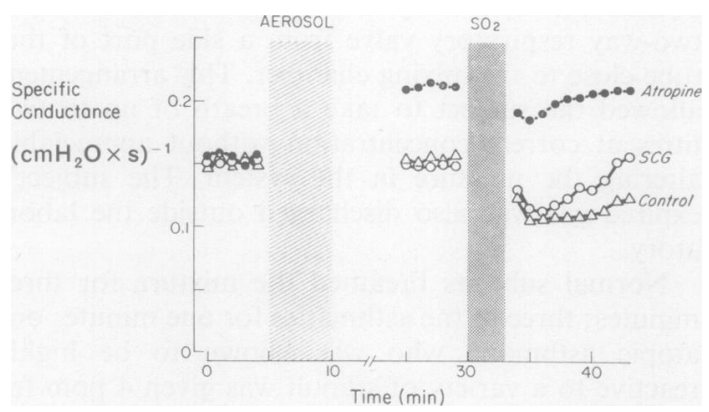

Fig 1 Response of one normal subject to three exposures to $\mathrm{SO}_{2}$, showing the protective effect of atropine and sodium cromoglycate (SCG). After baseline measurements of sGaw the subject inhaled an aerosol, which in separate experiments was water $(-\triangle-)$, atropine methonitrate $(0 \cdot 2 \%)(-\mathrm{O}-)$ and sodium cromoglycate (1\%) (-○-). After inhaling atropine the subject bronchodilated. Inhalation of $8 \mathrm{ppm} \mathrm{SO} \mathrm{S}_{2}$ caused a transient fall of sGaw which was greatest in the control experiment.

conductance (sGaw) in all subjects. The mean rise of Raw was $56 \cdot 8 \pm 46 \cdot 1 \%$ and the mean fall of sGaw was $34.4 \pm 17.3 \%$. Changes in Vtg were less consistent, but the mean effect was a $4.9 \pm 11.2 \%$ rise. The lowest value of sGaw was usually during the first two minutes after exposure.

Although all the subjects noticed the unpleasant taste of $\mathrm{SO}_{2}$ and had a feeling of irritation in the throat, symptoms related to broncho-constriction were mild or absent in nine subjects. Two subjects with the greatest conductance changes were moderately distressed by chest tightness with wheezing for five minutes after inhalation.
Asthmatics ( fig 2)

Raw and Vtg rose by $77 \cdot 5 \pm 58.9 \%$ and $9.6 \pm 9.7 \%$ respectively after $\mathrm{SO}_{2}$ inhalation. The mean fall of $\frac{\mathrm{C}}{\mathrm{C}}$ sGaw was $44.5 \pm 22 \cdot 5 \%$. All subjects noticed mild chest tightness.

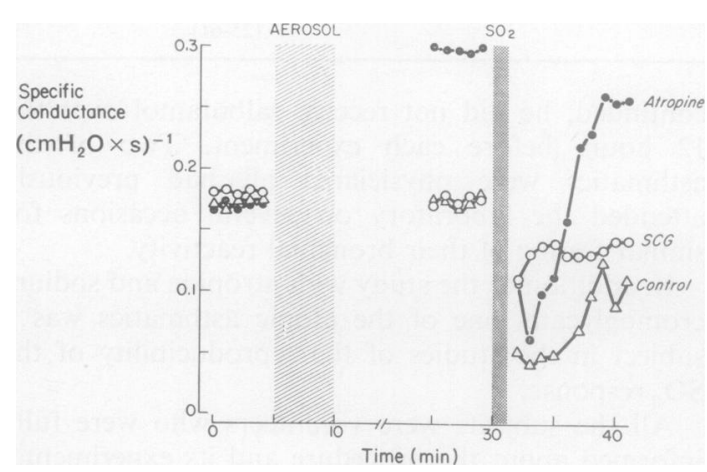

Fig 2 Response of one asthmatic subject to three exposures to $\mathrm{SO}_{2}$ showing the effect of atropine and sodium cromoglycate.

\section{EFFECT OF ATROPINE (TABLE 2)}

Normal subjects (figs 1, 3, 5)

All but one subject bronchodilated in response to atropine. Raw decreased by $24 \cdot 2 \pm 19 \cdot 1 \%(\mathrm{p}<0.01)$

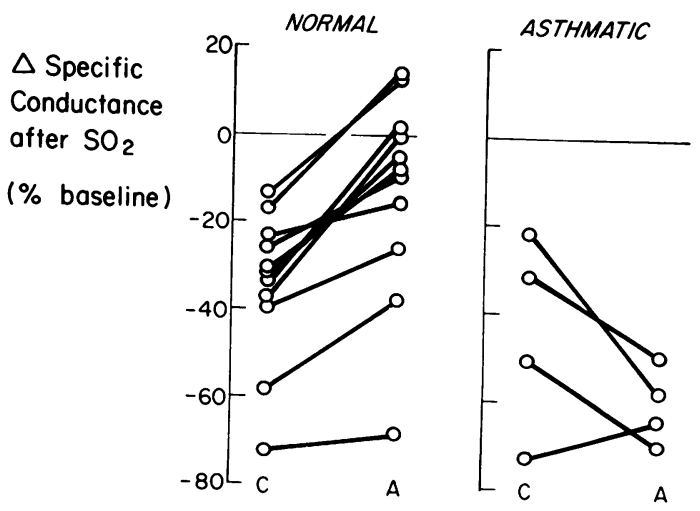

Fig 3 Effect of atropine on the bronchial response to $\mathrm{SO}_{2}$ in normal and asthmatic subjects. The change in sGaw after $\mathrm{SO}_{2}$ inhalation is shown for each subject in the control $(C)$ and atropine $(A)$ experiment. Atropine antagonised the reaction to a variable degree in normals but not in asthmatics.

Vtg by $9.7 \pm 18.2 \%(\mathrm{p}>0 \cdot 2)$; and sGaw increased by $58.2 \pm 51.8 \%(\mathrm{p}<0.001)$.

After $\mathrm{SO}_{2}$ inhalation the mean fall of $\mathrm{sGaw}$ from the post-atropine control level was $12.7 \pm 24.0 \%$ 


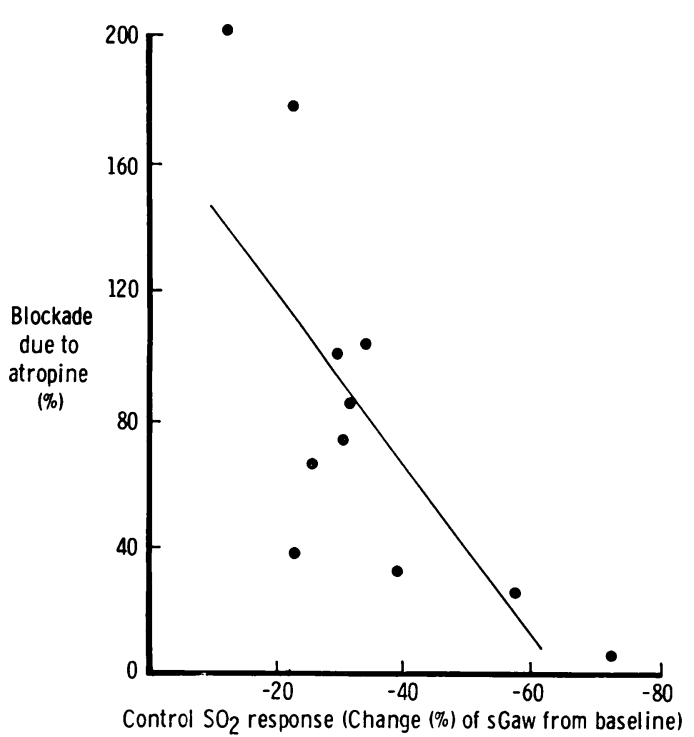

Fig 4 Relationship between size of the control response to $\mathrm{SO}_{2}$ and degree of blockade of the response by atropine in normal subjects. The blockade is calculated as [(Control $\mathrm{SO}_{2}$ response-Atropine $\mathrm{SO}_{2}$ response) $\times 100 \% /$ Control $\mathrm{SO}_{2}$ response] where "response" is measured as change in sGaw. Values in excess of $100 \%$ occur when, after atropine, the subject responds to $\mathrm{SO}_{2}$ with slight bronchodilatation. Small $\mathrm{SO}_{2}$ responses are completely or largely blocked by atropine but there is much less blockade of the larger $\mathrm{SO}_{2}$ responses $(y=$ $-2.69 \times 175 ; r=-0.75 ; p<0.01)$.

$(\mathrm{p}<0.05)$. Three subjects bronchodilated in response to $\mathrm{SO}_{2}$ and in one subject there was no change (fig 3). In all subjects the percentage fall in sGaw after $\mathrm{SO}_{2}$ was less than after the control exposure $(p<0.001)$. The degree of protection conferred by atropine was inversely related $(r=-0.75 ; p<0.01)$ to the size of the subject's response to $\mathrm{SO}_{2}$, so that while small responses were completely abolished by atropine, there was little blockade of the largest responses (figs 3 and 4). There was no significant relationship between the degree of bronchodilatation caused by atropine and the degree of protection.

\section{Asthmatics ( figs 2, 3, 5)}

After atropine inhalation Raw fell by $31 \pm 11 \%$; Vtg rose by $15 \pm 23 \%$; sGaw rose by $41 \pm 36 \%$.

There was, however, minimal blockade of the bronchial response to $\mathrm{SO}_{2}$ seen in one subject only. In three subjects the fall in sGaw as a percentage of the post-atropine control level was greater than without atropine (fig 3 ). In two subjects a lower absolute level of sGaw was reached after $\mathrm{SO}_{2}$ in the

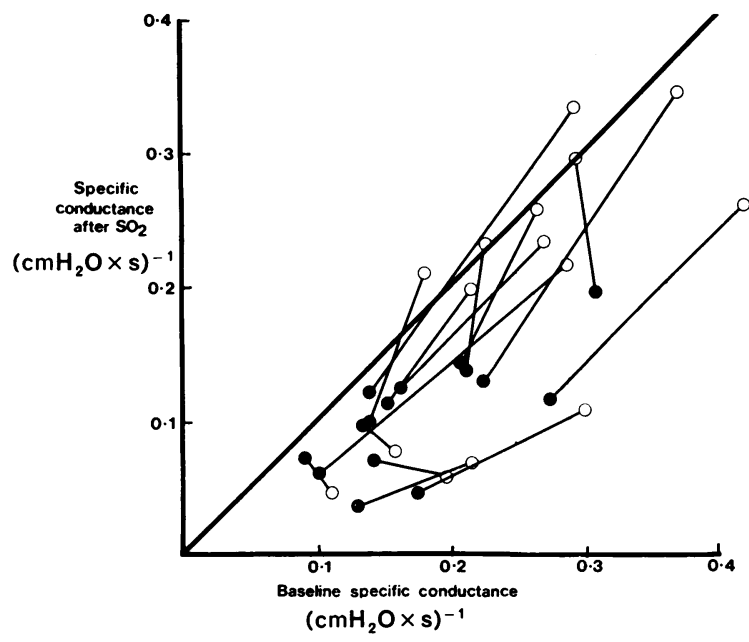

Fig 5 Effect of atropine on baseline sGaw and on response to $\mathrm{SO}_{2}$ in normal and asthmatic subjects (before atropine $=0 ;$ after atropine $=0$ ). After atropine baseline sGaw is increased in all but one subject and the $\mathrm{SO}_{2}$ response is usually diminished, as shown by the closer grouping of post-atropine points around the line of identity (-). In several subjects, however, the effect of atropine is to increase sGaw parallel to the line of identity. The absolute magnitude of their response is thus unaltered, but it is smaller when represented as a percentage of the higher baseline sGaw. In five subjects (four asthmatic; one normal) atropine displaces the points away from the line of identity and in three of these the absolute sGaw after $\mathrm{SO}_{2}$ is lower in the atropinised state.

atropinised state despite the higher level of the control readings after atropine (fig 5).

EFFECT OF SODIUM CROMOGLYCATE (TABLE 2)

\section{Normal subjects (figs 1 and 6)}

Inhalation of sodium cromoglycate had no significant effect on Raw or sGaw. After $\mathrm{SO}_{2}$ there was a significant rise in Raw (mean $15.5 \pm 23.6 \%$ ) and fall of sGaw (mean $16.1 \pm 11.9 \%)(p<0.001)$ from baseline levels, though in all subjects but one the changes were smaller than with the control exposure.

\section{Asthmatics ( fig 6)}

There was a fall in sGaw (mean $24.0 \pm 20.9 \%$ ) after sodium cromoglycate inhalation because of a rise in Raw (mean $39 \cdot 6 \pm 58 \cdot 1 \%$ ). After $\mathrm{SO}_{2}$ the change in sGaw was less than half that of the control exposure (mean fall $15 \cdot 2 \pm 15 \cdot 4 \%$ ). In two atopic subjects, the response was effectively abolished in the presence of sodium cromoglycate while in one subject the response was considerably diminished. The nonallergic subject showed no protection from the drug. 

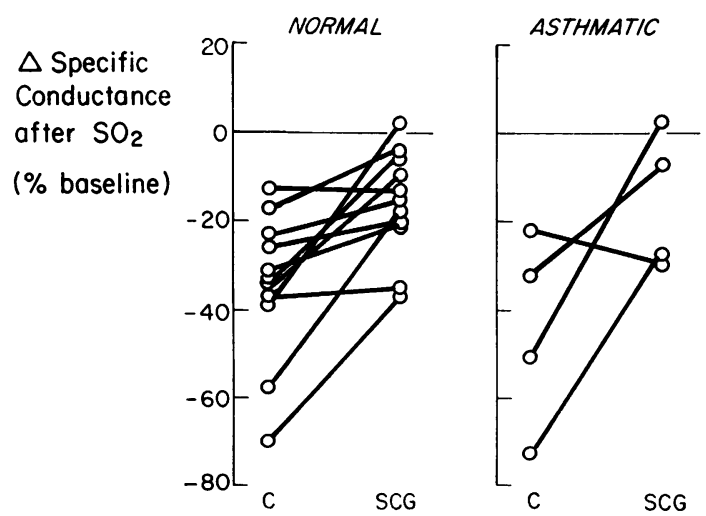

Fig 6 Effect of sodium cromoglycate on the bronchial response to $\mathrm{SO}_{2}$ in normal and asthmatic subjects. The change in sGaw after $\mathrm{SO}_{2}$ inhalation is shown for each subject in the control $(C)$ and sodium cromoglycate $(S C G)$ experiment. Sodium cromoglycate diminished the $\mathrm{SO}_{2}$ response in most asthmatic and normal subjects.

The effect of sodium cromoglycate on asthmatics, therefore, did not reach statistical significance.

\section{REPETITION OF THE $\mathrm{SO}_{2}$ RESPONSE (FIG 7)}

At four hours the $\mathrm{SO}_{2}$ response decreased from a control fall of sGaw of $35.5 \pm 11.4 \%$ to a fall of 20.6 $\pm 15.5 \%(n=5)$. The four-hour response was smaller in each subject. Tachyphyllaxis was hardly detectable at 24 hours when the fall of sGaw was $24.6 \pm$ $25.8 \%$, compared with a control fall of $28.9 \pm 27.5 \%$ $(n=4)$. Baseline values of Raw, Vtg, or sGaw before the first and second exposures did not change.

\section{Discussion}

The rapid onset and recovery of the bronchial response to $\mathrm{SO}_{2}$ suggest that active bronchoconstriction is occurring. The response can be prevented by beta-sympathomimetic agents ${ }^{2}$ and by taking deep breaths (personal observations in normal subjects), confirming the importance of active bronchoconstriction. However, narrowing of the glottis and mucosal swelling may play a smaller part in causing airflow obstruction. We administered propranolol to normal subjects before each challenge in the hope of increasing the subjects' reactivity, thus allowing a lower degree of exposure to $\mathrm{SO}_{2}$. Jones ${ }^{6}$ demonstrated that in normal subjects propranolol increased the lability of bronchial tone that occurred with exercise. Additionally we hoped that propranolol, by diminishing the variable influence of the sympathetic nervous system, would decrease the variability of response between tests.

In most normal subjects, inhalation of atropine

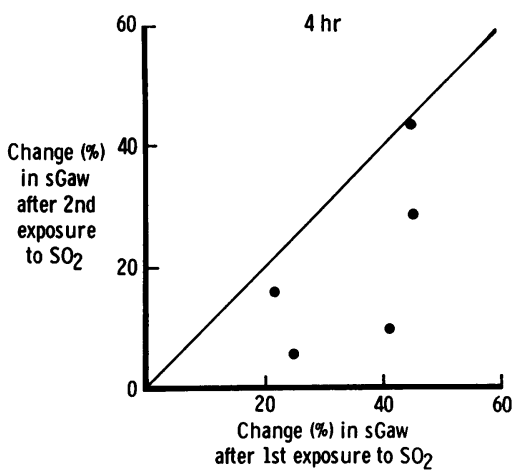

(a)

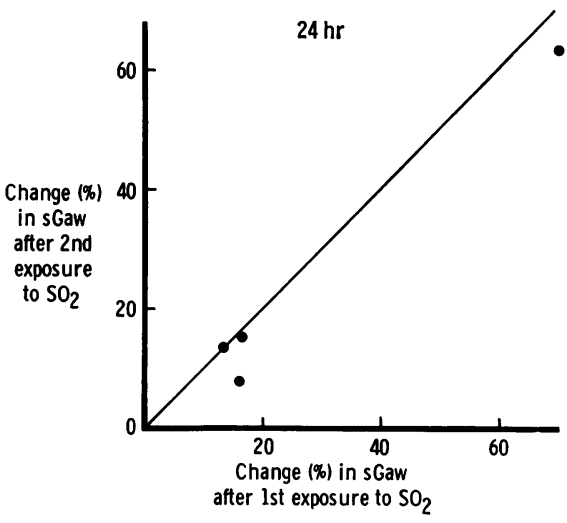

(b)

Fig 7 Reproducibility of the $\mathrm{SO}_{2}$ response after intervals of four and 24 hours. At four hours (a) the responses are smaller and therefore fall beneath the line of identity $(y=0.9 x-11 \cdot 2)$ whereas this effect is much less marked at 24 hours $(b)(y=1.05 x-1.4)$.

considerably attenuated the bronchial response to $8 \mathrm{ppm} \mathrm{SO}_{2}$. This is in agreement with Nadel et $\mathrm{al}^{3}$. who blocked the response to 4-6 ppm $\mathrm{SO}_{2}$ with subcutaneously administered atropine. Thus, in $\frac{D}{O}$ normal subjects, the effect of $\mathrm{SO}_{2}$ is mediated wholly, or in part, by a cholinergic mechanism. $\mathrm{SO}_{2}$ is $\mathrm{a}_{\sigma}^{N}$ highly soluble gas and is largely absorbed in the pharynx and upper airways ${ }^{8-10}$ where it may stimulate vagal and glossopharyngeal afferent endings, leading $\mathrm{\omega}$ to a bronchoconstrictive cholinergic reflex. However,, we found little or no evidence of such a reflex mechanism in hyperreactive normal and asthmatic subjects in whom atropine did not block the response. These findings are in agreement with those of $\frac{0}{0}$ Booij-Noord et $a l^{2}$ who found that the $\mathrm{SO}_{2}$ response in asthmatics was not significantly inhibited by either an anticholinergic agent or a ganglion blocker. In the normal subjects we found an inverse relation? 
ship between bronchial reactivity to $\mathrm{SO}_{2}$ and the degree to which the response could be blocked with atropine: the largest reactions were least blocked. The asthmatic subjects were more reactive than the most reactive normal subjects and in this group atropine had the least protective effect. Thus, no cholinergic reflex mechanism appears to be involved in the bronchial response to $\mathrm{SO}_{2}$ in these asthmatics. It remains possible that a non-cholinergic reflex pathway may be involved. For instance, the efferent limb of such a reflex could involve purinergic or alphaadrenergic nerves and therefore be unaffected by atropine.

The delivery of atropine to the airways was probably similar in the two groups since their degrees of bronchodilatation were similar. Thus, after atropine inhalation the conductance in the asthmatics increased by $41 \%$, and in the normal subjects by $52 \%$.

We cannot explain the blocking action of sodium cromoglycate on the bronchial response to $\mathrm{SO}_{2}$. The drug inhibits the release of pharmacologically active amines after an antigen-antibody reaction by stabilising the mast cell membrane, ${ }^{11}$ but mast cell degranulation by $\mathrm{SO}_{2}$ has not been demonstrated. ${ }^{12}$ Although sodium cromoglycate does not act directly on bronchial smooth muscle and is not a direct pharmacological antagonist of acetylcholine or histamine, ${ }^{13}$ it does attenuate the vagal reflex component of the bronchial response to histamine, 1415 probably by indirectly desensitising lung irritant receptors. Thus, sodium cromoglycate may decrease the stimulation of irritant receptors by $\mathrm{SO}_{2}$ and hence inhibit the reflex component of the reaction. Such a mechanism is unlikely to be important in blocking the $\mathrm{SO}_{2}$ response in asthmatics in whom we were unable to demonstrate cholinergic reflex effects of $\mathrm{SO}_{2}$. This leaves open the question of whether sodium cromoglycate blocks the cholinergic reflex effects of $\mathrm{SO}_{2}$ in normal subjects, or whether a non-cholinergic reflex may be blocked in both groups.

Tachyphyllaxis of the bronchial response to $\mathrm{SO}_{2}$ was first described by Frank et al ${ }^{16}$ who showed that when an $\mathrm{SO}_{2}$ challenge was repeated after 15 minutes, the second response was smaller. This effect was not seen when the interval between responses was one month or more. We have shown attenuation of the response after four hours which was much less at 24 hours. The mechanism of this effect is not known. We hypothesise that $\mathrm{SO}_{2}$ produces bronchoconstriction by reacting with a receptor which is damaged or destroyed in the process, and is slowly regenerated over the next 24 hours or more.
We wish to thank Dr Roger Altounyan for the idea behind this project and for material assistance in its conduct.

\section{References}

${ }^{1}$ Sim VM, Pattle RE. Effect of possible smog irritants on human subjects. JAMA 1957;165:1908-13.

${ }^{2}$ Booij-Noord H, Orie NGM, Berg W Chr, De Vries K. Results of provocation of human bronchial airways with allergic and non-allergic stimuli and of drug protection tests. In: Orie NGM, Van der Lende R, eds. Bronchitis III. Proc 3rd Int Symp on Bronchitis. Assen: Royal Vangorcum, 1969:316-30.

${ }^{3}$ Nadel JA, Salem H, Tamplin B, Tokiwa Y. Mechanism of bronchoconstriction during inhalation of sulfur dioxide. J Appl Physiol 1965;20:164-7.

+ De Vries K, Gökemeijer JDM, Orie NGM, Peset R, Sluiter HJ. Bronchial tree response of the allergic and non allergic stimuli in patients with generalized obstructive lung disease. Bull Int Uni Tuberc 1976;51:617-9.

${ }^{5}$ Snashall PD, Lewin C. Mechanisms of sulfur dioxide induced bronchoconstriction in man. Am Rev Respir Dis 1976;113: Suppl. abstr. 87.

6 Jones RS. Significance of effect of beta blockade on ventilatory function in normal and asthmatic subjects. Thorax 1972;27:572-6.

7 Dubois AB, Botelho SY, Comroe JH Jr. A new method for measuring airway resistance in man using a body plethysmograph: values in normal subjects and in patients with respiratory disease. J Clin Invest 1956;35: 327-35.

${ }^{8}$ Balchum OJ, Dybicki J, Meneely GR. Pulmonary resistance and compliance with concurrent radioactive sulfur distribution in dogs breathing $\mathrm{S}^{35} \mathrm{O}_{2} . J$ Appl Physiol 1960;15:62-6.

${ }^{9}$ Strandberg LG. $\mathrm{SO}_{2}$ absorption in the respiratory tract. Arch Environ Health 1964;9:160-6.

${ }^{10}$ Speizer FE, Frank NR. A comparison of changes in pulmonary flow resistance in healthy volunteers acutely exposed to $\mathrm{SO}_{2}$ by mouth and nose. Br J Ind Med 1966; 23:75-9.

${ }^{11}$ Cox JSG. Disodium cromoglycate (FPL 670) (Intal): a specific inhibitor of reaginic antibody-antigen mechanisms. Nature 1967;216:1328-9.

12 Altounyan REC. Review of the clinical activity and modes of action of sodium cromoglycate. In: Pepys J, Edwards AM, eds. The mast cell. London: Pitman Medical, 1980; 199-216.

${ }^{13}$ Cox JSG, Beach JE, Blair AMJN et al. Disodium cromoglycate (Intal). Adv Drug Res 1970;5:115-93.

${ }^{14}$ Kerr JN, Govindaraj M, Patel KR. Effect of alphareceptor blocking drugs and disodium cromoglycate on histamine sensitivity in bronchial asthma. $\mathrm{Br}$ Med $\mathrm{J}$ 1970;2:139-41.

15 Jackson DM, Richards IM. The effects of sodium cromoglycate on histamine aerosol-induced reflex bronchoconstriction in the anaesthetized dog. Br J Pharmacol $1977 ; 61: 257-62$.

16 Frank NR, Amdur MO, Whittenberger JL. A comparison of the acute effects of $\mathrm{SO}_{2}$ administered alone or in combination with $\mathrm{NaCl}$ particles on the respiratory mechanics of healthy adults. J Air Wat Poll 1964;8:125-33. 